Volume 19

Issue 2 June

June 1983

\title{
Smuggling in Maine During the Embargo and the War of 1812
}

Harvey Strum

Follow this and additional works at: https://digitalcommons.colby.edu/cq

\section{Recommended Citation}

Colby Library Quarterly, Volume 19, no.2, June 1983, p.90-97

This Article is brought to you for free and open access by Digital Commons @ Colby. It has been accepted for inclusion in Colby Quarterly by an authorized editor of Digital Commons @ Colby. 


\title{
Smuggling in Maine during the Embargo and the War of 1812
}

\author{
by HARVEY STRUM
}

S EEKING to pressure the British into respecting American neutral rights, Congress and President Thomas Jefferson imposed an embargo on trade in December 1807. As a result of the embargo American exports dropped from \$108 million in 1807 to \$22 million in 1808 . Prices for agricultural produce plummeted, laborers and seamen were thrown out of work in the seaports, and businessmen and merchants suffered huge losses driving many into bankruptcy. While the people of the South, the West, Pennsylvania, Maine, and part of New York remained loyal to the Republican cause, the embargo drove many normally Republican voters to cast ballots for the Federalists. A Federalist resurgence developed in New England, Delaware, Maryland, New Jersey, and New York. The Federalists doubled their representation in Congress and either increased the number of seats they held or gained majorities in state assemblies in the New England and Middle Atlantic states.

In response to the economic hardship produced by the embargo, widespread smuggling developed in northern New York, Vermont and New Hampshire, southern Georgia, coastal New England, and North Carolina. Juries in many towns, especially in New York and New England, refused to convict violators of the embargo, and residents demonstrated great hostility toward revenue officers and militia who tried to enforce the law. Although Maine remained loyal to the Republican party, unlike most of the rest of Massachusetts, many of the residents of Maine either condoned smuggling or engaged in it. Maine emerged as one of the most notorious centers of the illegal trade with Canada as residents driven by hard times resorted to smuggling to earn a livelihood.

The imposition of the embargo had a disastrous impact upon Maine. Just prior to the embargo, Portland was one of the most prosperous communities in New England. However, by early 1808, eleven commercial houses could no longer pay their debts. Many of Portland's leading merchants and shipowners failed. The unemployment rate rose to approximately $60 \%$ of the workers in Maine's coastal towns. Some of the more prosperous citizens of Portland contributed to the establish- 
ment of a soup kitchen for the unemployed, which provided one free soup dinner a day for the men out of work and their families.'

Towns all along the Maine coast reported the same disastrous effects of the embargo. In Wiscasset, shipowner Moses Carlton went from wealth to poverty as thirty of his vessels lay rotting at the wharves. Commodities perished in the warehouses of Castine. Lumber ready for shipment from Augusta lay piled along the river decaying as the price of lumber dropped from $\$ 14$ per 1000 boards to $\$ 5.50$. Whether in Wells, Wiscasset, Portland, Augusta, or Castine, the sight of rotting goods and ships, of bankrupt merchants and shipowners, and of unemployed men became commonplace. ${ }^{2}$

The hard times produced by the embargo and uncertainty over land titles led to violence. In early 1808 , a band of men, dressed as Indians, attacked a sheriff in Kennebec County, wounding the sheriff and killing his horse. Armed and masked men shot at, stripped, and severely beat officers of the law in Lincoln County. A mob attacked a sheriff near Frankfort in April 1808. ${ }^{3}$

Frankfort merchants refused to give credit to settlers, and the settlers, because of the hard times produced by the embargo, lacked the cash to pay for food and other goods for their families. Merchants in Frankfort did not think it safe to keep large stocks of corn and flour because the local residents threatened to take the food by force if the merchants refused to give them credit. Residents of Machias threatened to burn down the house of the customs collector, and the inhabitants of Passamaquoddy insulted and threatened the collector of customs and his deputies. $^{4}$

Maine's proximity to Canada encouraged smuggling. By May, over one hundred vessels stood ready to smuggle goods across Passamaquoddy Bay into Canada. Local residents were hired for $\$ 2$ per day to guard smuggled goods which under the cover of fog were sent to Canada. Eastport emerged as one of the busiest ports in the United States for the shipment of flour to Nova Scotia and New Brunswick. Smugglers brought in British goods from St. Andrews and deposited the contraband at Robbinston or along the shore between West Quoddy and the Machias River. ${ }^{5}$

Alarmed at the widespread smuggling, General Henry Dearborn informed President Jefferson that gunboats would be needed all along the

1. Portland Eastern Argus, January 21, 28, August 18, 1808; William Willis, The History of Portland (Somersworth, N.H., 1972 facsimile edition of 1865 original), p. 574; Ronald Banks, Maine Becomes $a$ State (Middletown, Conn., 1970), p. 57.

2. Hartford Connecticut Courant, February 3, 1808; Edward Browne, History of Wells \& Kennebunk (Portland, 1875), pp. 590-91; William Jordan, History of Cape Elizabeth, Maine (Portland, 1965), p. 57; Charles Nash, History of Augusta (Augusta, 1904), p. 184; “Jones's Eddy," Collections of the Maine Historical Society, IV (1856), 47.

3. New York Commercial Advertiser, February 4, May 6, 13, June 13, 1808; Portland Eastern Argus, February 18, 25, June 16, 1808; Hartford Connecticut Courant, February 3, May 18, 1808.

4. New York Commercial Advertiser, June 28, 1808; New York Evening Post, May 4, 9, 1808.

5. Henry Kilby, Eastport and Passamaquoddy (Eastport, 1888), pp. 142-55. 
coast of Maine to stop the smuggling. President Jefferson despatched the sloop of war Wasp and several gunboats to Passamaquoddy with orders to seize all deposits of flour and assist the customs officers to enforce the law. The customs collector at Eastport hired men to act as sentinels along the coast and report embargo violators. Government forces captured many of the smugglers. On one night alone, the Wasp seized fourteen boats with illegal goods. During the summer of 1808 , the collector at Castine seized the Angenora while the ship was loading a cargo of boards at Bangor. ${ }^{6}$

In spite of all their efforts, government forces could not stop the smuggling. Under the cover of every fog hundreds of barrels of flour were carried across Passamaquoddy Bay. Smugglers bribed, threatened, and physically restrained customs officers and their deputies, but on many occasions the smugglers simply outwitted or outran the customs officers. Frequently, smugglers and government forces exchanged gunfire in eastern Washington County as government forces tried to capture the smugglers before they crossed the Canadian line.'

Evasions of the embargo were not limited to the region between Machias and Robbinston but took place all along Maine's coast. The inhabitants of the Penobscot Bay area so flagrantly violated the law that President Jefferson issued a statement condemning the residents of the Penobscot for their disrespect for the law. In January 1809 alone ten vessels escaped from the Penobscot and evaded capture. Captain Benjamin Thomas of Camden, for example, took his schooner out of Camden harbor one night and sailed to the West Indies. After selling his cargo Thomas returned to Camden but hid the proceeds of his voyage in the schooner to escape detection by the customs officers. ${ }^{8}$

One of the most notorious smuggling incidents took place in the fall of 1808 near Isle au Haut. The collector of customs at Castine deposited some captured flour and rice on the island and sent five men to stand guard. The schooner Peggy with a crew of fourteen men from Eastport and Buckstown landed near the island. After killing one of the guards, the smugglers escaped with 150 barrels of flour and rice. However, the collector of customs at Castine organized a posse of volunteers and gave chase. After a ten mile chase, the revenue cutter caught the Peggy and captured the fourteen smugglers. Eight of the smugglers were indicted for murder, but in mid-November a band of fifteen armed and disguised men broke into the Castine jail and released the eight men, who successfully made their escape. ${ }^{9}$

6. New York Commercial Advertiser, July 6, 1808.

7. Ibid., June 28, 1808; Portland Eastern Argus, May 19, 1808.

8. New York Evening Post, May 9, 1808, February 6, 11, 1809; Hartford Connecticut Courant, February 8, 1809; Thomas Jefferson to Albert Gallatin, October 4, 1808, Albert Gallatin Papers, New York Historical Society (NYHS).

9. New York Evening Post, December 3, 1808; Portland Eastern Argus, November 24, December 8, 1808; Boston Centinel, November 29, 1808, January 3, 1809. 
Down the coast the Kennebec River region emerged as a third major center of smuggling. General Dearborn wrote the Secretary of the Treasury, Albert Gallatin, to complain about the widespread violations of the embargo along the Kennebec. In one incident, the brig Mary Jane was taking on a cargo of provisions at Bath when the collector of customs decided to try to prevent the ship's escape. The collector hired a cutter, armed it with two four pounders and a swivel and got a crew of volunteers to man the cutter. When the Mary Jane set sail the cutter tried to prevent the vessel's escape and opened fire on the Mary Jane. After exchanging shots with the cutter, the Mary Jane managed to run past the cutter and fled past the U.S. fort downriver before it could open fire. ${ }^{10}$

Another confrontation between smugglers and customs officers took place when the customs collector tried to prevent the Sally from leaving Bath. Neither the fire from the revenue cutter nor fire from the fort stopped the Sally. As the Sally made its escape hundreds of local townspeople, who came down from Bath in thirty sleighs to watch the flight of the Sally, cheered the smugglers. ${ }^{11}$

Portland and Cape Elizabeth were also centers for large scale smuggling activities. At Cape Elizabeth, citizens would load their vessels at night and sneak out. Some smugglers were so daring and so quick they successfully loaded their ships during daylight and slipped past the harbor entrance forts, Preble and Scammel, which residents called the "Embargo Forts."' Vessels regularly slipped out of Portland at night for the West Indies and Halifax. In the fall of 1808, two hundred armed and masked men took possession of the Portland wharves, loaded two vessels and successfully escaped from the harbor. Not all those who attempted to sneak out of Portland were as lucky. When, in the middle of January 1809 , a small sloop tried to leave Portland ostensibly to go clamming, a gunboat saw the vessel and opened fire. The sloop continued to flee but the gunboat gave chase and caught the sloop. ${ }^{12}$

The embargo split the people of Maine. Slightly over a majority continued to vote Democratic-Republican and in the summer and fall of 1808 Democratic-Republicans expressed their approval of the embargo. Federalists, however, organized public protests against the law and petitioned the Massachusetts legislature and Congress against the embargo. In Bath, the town meeting voted for the establishment of a committee of safety to warn the town's residents of any attempt by the customs collector and the military to enforce the law. Residents of Bath authorized the committee of safety to give immediate alarm if "any infringement

10. New York Evening Post, January 11, 19, 30, 1809; Boston Gazette, January 5, 12, 1809; New York Herald, January 8, 11, 19, 1809; Henry Dearborn to Albert Gallatin, July 24, August 29, 1808, Albert Gallatin Papers, NYHS.

11. New York Evening Post, January 30, 1809.

12. Ibid; Henry Dearborn to Albert Gallatin, July 24, 27, October 29, November 6, 1808, Albert Gallatin Papers, NYHS. 
of their rights shall be committed by any" customs or military officers. ${ }^{13}$

When Congress and President Jefferson lifted the embargo in early 1809 , many of the people of Maine rejoiced. Typical of the celebrations was one that took place in Wiscasset. After the President's proclamation removing the embargo was read to the assembled townspeople, the artillery and infantry companies paraded with their flags flying and drums beating. A few hours later, another parade of virtually all the citizens of the town was organized. About 250 men, 500 boys, and almost as many dogs paraded past an audience of the town's women and children. The marchers beat drums, played fifes, rang bells, and shouted for joy. After the parade, the people of Wiscasset finished their celebration with the extensive consumption of grog, brandy, wine, and rum. ${ }^{14}$

Following the removal of the embargo, a brief thaw developed in Anglo-American relations. However, the British continued to refuse to respect American rights at sea. Congress retaliated with various forms of commercial restrictions. Since these measures did not prove as restrictive as the embargo, smuggling did not become a major problem except in the area around Eastport. From 1809 to 1812 residents of Eastport continued to smuggle goods in from Canada. ${ }^{15}$

Then, in June 1812, Congress declared war on Great Britain. In spite of the war, many of Maine's lumbermen, merchants, fishermen, shipowners, and farmers resorted to trading illegally with the British in Canada. Eastport became the center of the Canadian-American trade during the first two years of the war. George Ulmer, a major-general in the militia, assumed command of the regular army troops stationed at Eastport, and he attempted to stop the illicit trade. ${ }^{16}$

Ulmer's men captured a number of vessels, such as the Betsey and the True American, that were trading with the British. On several occasions, though, the smugglers outwitted the government forces. In one incident, Ulmer discovered a vessel from Belfast loaded with a cargo of salt and clothes, and he sent an officer and fifteen men to prevent the vessel from leaving Eastport. Before Ulmer's men arrived, however, the vessel left port. Government forces chased the vessel for seven miles, but when two boats loaded with armed men appeared near the Canadian line, the American forces gave up the chase and returned to Eastport while the smugglers made it to safety in Canada.

13. Hartford Connecticut Courant, February 1, 1809; Jordan, p. 57; Portland Eastern Argus, July 4, 15, 21, August 3, October 6, 13, 20, November 3, 1808; Boston Gazette, January 5, 1809; Orchard Cook to Wood, Carleton and McCrate, January 14, 1808, Box 4, William King Papers, Maine Historical Society (MeHS); Francis Greene, History of Boothbay, Southport and Boothbay Harbor, Maine (Portland, 1906), pp. 248-49.

14. Captain John Binney to Mrs. Binney, April 27, 1809, Fannie Chase, Wiscasset in Pownalborough (Portland, 1941), pp. 328-29.

15. Kilby, pp. 155-57.

16. Ibid., pp. 158-72; George Ulmer to William King, January 15, March 19, 1813, Box 6, William King Papers, MeHS; Charles Clark, Maine (New York, 1977), p. 69; William Williamson, History of the State of Maine (Hallowell, 1832), II, 641-42; Banks, p. 59. 
In another incident, Ulmer suspected a certain Mr. Hutchins of Saco of planning to smuggle a load of beef into Canada. Hoping to foil Hutchins' plan, Ulmer had the beef seized and put under guard. When Hutchins tried to seize the beef, the guard apprehended Hutchins. Hearing of the arrest of Hutchins, some of the local townspeople went to see Ulmer and persuaded him to release Hutchins. The deputy sheriff promised Ulmer he would make sure Hutchins did not try to leave town. ${ }^{17}$

The next day, Hutchins and some accomplices got one of the guards drunk on rum and bribed two others. After taking the beef, Hutchins and his associates escaped to St. Andrews. When Hutchins returned to the United States, Ulmer ordered him arrested. Unfortunately, the sergeant who apprehended Hutchins and his three accomplices made the mistake of putting only two men to guard the four smugglers aboard the captured boat. The smugglers overpowered the guards and fled to St. Andrews, where they handed over the two soldiers to the British authorities. Ulmer had to bargain with the British commander to get his men back, and he never did catch Hutchins. ${ }^{18}$

The widespread smuggling in eastern Washington County led Ulmer to suspect a number of Eastport's leading citizens of conspiring to evade the embargo. Among those Ulmer suspected was a local representative to the state legislature, and Ulmer also believed that some of the local merchants conspired with the customs officers and officers of the militia to arrange the seizure of smuggled goods. Once the goods were seized they would be sold for a fraction of their value to another conspirator and then the goods could be legally resold in the United States. The efforts of Ulmer to stop the smuggling and his investigation into the conspiracy at Eastport to evade the law aroused the anger of Eastport's residents. After going through the motions of forming a committee to look into Ulmer's conduct, the townspeople arranged for his arrest on the charges of illegally seizing property. Ulmer was sent to jail in Machias, and he had to appeal to the government for help to get out of jail. ${ }^{19}$

To avoid seizure by Ulmer, smugglers at Eastport began to use the flags of neutral European powers to transport American produce and British manufactured goods to and from St. Andrews, Halifax, and St. John. Using this ruse, smugglers landed British goods on Campobello Island and then took them across to Eastport, and from there to Penobscot and eventually to Portland or Boston. Occasionally, smugglers risked traveling further down the coast using the flag of Sweden as their cover. The brig Margaretta, for example, sailed under Swedish colors but was owned by a native of New Hampshire. At St. John, the Margar-

17. George Ulmer to William King, January 14, March 3, 1813, William King Papers, MeHS.

18. George Ulmer to William King, March 3, 1813, William King Papers, MeHS.

19. George Ulmer to William King, January 15, February 12, March 3, 1813, William King Papers, MeHS. 
etta filled up with British goods and landed the goods at Bath for shipment to Portsmouth. ${ }^{20}$

During the summer and fall of 1814, the British attacked Maine and captured all of coastal Maine east of the Penobscot River. Eastport continued to heavily import British goods for delivery west of the Penobscot. However, the center of the illegal trade shifted westward from Eastport to Castine and Hampden. Smugglers brought flour, fish, beef, and lumber to Castine to trade for British manufactured goods and sugar from the British West Indies. So many merchants and traders converged on Castine that virtually all the buildings in Castine near the water were converted into stores and a number of new buildings had to be constructed to meet the demand for space. ${ }^{21}$

Peleg Tallman of Bath arrived in Hampden to assume the position of Swedish Vice-Consul for Maine. Under the cover of the Swedish flag, British goods were shipped from Castine to Hampden. Droves of cattle came from western Maine to feed the British occupying forces in Castine. When ice closed the Penobscot, smugglers resorted to sleighs to continue the profitable trade. ${ }^{22}$

Smugglers resisted efforts by customs officers and the military to stop the trade with the British. When an agent of the customs collector at Hampden seized a loaded sleigh, the owner had the customs agent arrested for highway robbery, and the agent soon found himself in jail in Augusta. Like Ulmer, the customs agent had to appeal to the federal government to get free. When, in December 1814, Joseph Hook, the customs collector at Hampden, seized another drove of cattle, a group of fifteen men liberated the cattle and made off with a good part of the herd before customs agents could stop them. ${ }^{23}$

Smuggling was so widespread that even officers of the law engaged in it. During the autumn of 1814, Francis Cook, the customs collector at Wiscasset, stopped an unusual looking wagon owned by Sheriff Adams of Hancock County. While searching the wagon, Cook found it had a false bottom beneath which lay a load of illegal British goods. Cook confiscated the goods, and the incident of "the Double Bottomed Wagon" became something of a joke throughout Maine and came back to haunt Sheriff Adams. ${ }^{24}$

The illegal trade with the British flourished through the winter of 1814-15 until February when the War of 1812 ended. While the majority

20. Kilby, pp. 170-213; Charles Tappan to Captain Prebble, September 9, 1873, Bangor Historical Magazine, III (1887-1888), 203. In the same issue: "Smuggling in Maine in 1813," 105-08.

21. New York Evening Post, November 9, 24, 1814; Munson Gorham, Penobscot (New York, 1959), pp. 99-102; W. Williamson, II, 642-43, 650-55; George Wheeler, History of Castine (Bangor, 1875), pp. 145-47.

22. New York Evening Post, November 29, 1814; Banks, Maine, p. 59.

23. Joseph Williamson, "Smuggling on the Penobscot, 1814," Bangor Historical Magazine, III (1887-1888), 167.

24. John Johnston, A History of the Towns of Bristol and Bremen in the State of Maine (Albany, 1873), p. 416; Chase, p. 333; Boston Patriot, November 9, 1814. 
of Maine's residents supported the war and the Democratic-Republican party of President James Madison, the temptation to trade with the British proved irresistible for many of the people of Maine and illegal trade flourished almost as much during the war as it had during the embargo. The War of 1812 severely hurt the mercantile economy of coastal Maine. In Portland, seeing ragged and half-starved children roaming the streets, ships rotting on the wharves, and unemployed men became common. The people of Portland endured watered rum, sanded sugar, and shortweighted flour and crackers. Consequently, the news of the restoration of peace brought rejoicing. At Cape Elizabeth, people rang church bells, fired cannons, and shot off fireworks, and the people of Portland drank and danced to exhaustion when news of peace arrived. ${ }^{25}$

Both the embargo and the War of 1812 produced hard times in Maine. For many the opportunities provided by smuggling proved too tempting and too lucrative to resist. During the embargo, smuggling flourished all along the Maine coast and nothing the customs officers nor the military could do stopped the illegal trade. When the War of 1812 began, Eastport emerged as the major center for trade with the British. In 1814, the smuggling shifted to the Penobscot and British goods flooded Maine. Attempts to stop the trade failed and smuggling flourished until the war ended. ${ }^{26}$

During both the embargo and the War of 1812 large segments of the American people refused to support policies that created severe economic hardship. While all Americans resented the British violations of American neutral rights, many of the people of Maine did not believe a policy of economic coercion would work, and were not willing to accept the personal sacrifice required to pressure the British into respecting American maritime rights. Many of the residents of Maine rejected the Jeffersonian experiment in enforced civic virtue demanded by the embargo laws. Similarly, the War of 1812 was unpopular with a large part of the rest of the American population. The widespread trade with the British which developed in Maine reflected the war's unpopularity as well as the reality that for many of Maine's residents economic survival and economic profit proved more persuasive than appeals to patriotism in an unpopular and unsuccessful war.

Syracuse University

New York

25. New York Evening Post, February 3, 1814; Walter Copp, "Nova Scotian Trade During the War of 1812," Canadian Historical Review, XVIII (1937), 141-55.

26. Chase, p. 332; New York Commercial Advertiser, May 12, 1814. 